\title{
Common snook fed in alternate and continuous regimens with diet supplemented with Bacillus subtilis probiotic
}

\author{
André Pedro Noffs ${ }^{(1)}$, Leonardo Tachibana( ${ }^{(1)}$, Antenor Aguiar Santos ${ }^{(2)}$ and Maria José Tavares Ranzani-Paiva ${ }^{(1)}$ \\ (1)Agência Paulista de Tecnologia dos Agronegócios, Instituto de Pesca, Avenida Francisco Matarazzo, no 455, Parque da Água Branca, \\ CEP 05001-900 São Paulo, SP, Brazil. E-mail: andrenomia@yahoo.com.br, Itachiba@gmail.com, mase@pesca.sp.gov.br (2)Centro \\ Universitário Adventista de São Paulo, Estrada de Itapecerica, no 5.859, CEP 05858-001 São Paulo, SP, Brazil. E-mail: antenorbio@gmail.com
}

\begin{abstract}
The objective of this work was to evaluate the addition of Bacillus subtilis probiotic to the feed of common snook (Centropomus undecimalis) fingerlings, in alternate and continuous regimens. Six hundred and sixty fish, with average length of $5.90 \pm 0.88 \mathrm{~cm}$ and weight of $1.92 \pm 0.28 \mathrm{~g}$, were stocked in 12 cages of $1.0 \mathrm{~m}^{3}$, with 55 fish each. The experimental design was completely randomized, with three treatments and four replicates. The treatments consisted of diet with the addition of probiotic, provided in alternate regimen for 7 days and in continuous regimen; besides a control without probiotic in the feed. Zootechnical performance, body composition, immune response, and blood parameters were evaluated. No significant differences were observed in zootechnical performance indexes and in body composition of fish treated with probiotic, when compared to the control. Fish from the alternate regimen showed an increment in respiratory burst and a lower total erythrocyte count than fish from the continuous regimen and the control. Fish from the continuous regimen did not differ from those of the control. The addition of Bacillus subtilis does not increase growth rates of common snook fingerlings; however, it has an immunostimulant action when supplied in alternate regimen.

Index terms: Bacillus subtilis, Centropomus undecimalis, hematology, immunostimulant, marine aquaculture, respiratory burst.
\end{abstract}

\section{Robalo-flecha alimentado em regimes alternado e contínuo com dieta suplementada com o probiótico Bacillus subtilis}

Resumo - O objetivo deste trabalho foi avaliar a adição de Bacillus subtilis, como probiótico, na ração de juvenis de robalo-flecha (Centropomus undecimalis), em regimes de alimentação alternado e contínuo. Foram estocados 660 peixes com comprimento médio de $5,90 \pm 0,88 \mathrm{~cm}$ e peso médio de $1,92 \pm 0,28 \mathrm{~g}$, em 12 tanques-rede de $1,0 \mathrm{~m}^{3}$, com 55 peixes cada um. Utilizou-se o delineamento experimental inteiramente casualizado, com três tratamentos e quatro repetições. Os tratamentos consistiram de ração adicionada de probiótico, fornecida em regime alternado de 7 dias e em regime contínuo; além de controle sem probiótico na ração. Avaliaramse: desempenho zootécnico, composição corporal, resposta imune e parâmetros hematológicos. Não houve diferença significativa nos índices zootécnicos e na composição corporal dos peixes tratados com probiótico, em comparação ao controle. Os peixes do regime alternado apresentaram incremento na explosão respiratória e menor contagem total de eritrócitos do que os do regime contínuo e do controle. Os peixes do regime contínuo não diferiram dos do controle. A adição de Bacillus subtilis não promove o crescimento de juvenis de rebalo-peva; no entanto, tem ação imunoestimulante quando fornecido em regime alternado.

Termos para indexação: Bacillus subtilis, Centropomus undecimalis, hematologia, imunoestimulante, piscicultura marinha, explosão respiratória.

\section{Introduction}

Probiotics may be defined as live microbial preparations that promote enhancements in the health and well-being of the hosts (Gatesoupe, 1999; Verschuere et al., 2000; Schrezenmeir \& Vrese, 2001). The use of probiotics has been reported in aquaculture (Balcàzar et al., 2007; Wang, 2007; Aly et al., 2008; Dias et al., 2012) and in marine fish farming (Carnevali et al., 2006; Son et al., 2009; Barbosa et al., 2011), showing their efficacy as growth promoters, immune stimulants, and bioremediators in water quality. According to Jatobá et al. (2008), probiotics can be a viable alternative to decrease the chemicals used in aquaculture.

Bacillus subtilis has been tested as a probiotic in fish culture. In in vitro studies, Aly et al. (2008) 
demonstrated that it inhibits the growth of Aeromonas hydrophila and Pseudomonas fluorescens; stimulates the immunity of Nile tilapia (Oreochromis niloticus), when added to the feed; and is effective in promoting the growth of treated animals, in comparison to the controls. Dias et al. (2012) observed an increase in the reproductive ability and in the phagocytic activity of matrinxã (Brycon amazonicus), when B. subtilis was added to the diet at a concentration of $10^{10}$ colony-forming units (CFU) per kg.

When analyzing microbial balance in common snook (Centropomus undecimalis) larvae, Kennedy et al. (1998) found that the exclusion of certain vibrio populations resulted in better survival rates, besides increasing the immunological capacity of the animals treated with a strain of $B$. subtilis isolated from the fish itself, when compared with untreated fish (control).

Appropriate parameters for probiotic regimens, including routes of administration, posology, and period of treatment must to be evaluated, in order to determine the ideal strategies for particular species and farming conditions (Nayak, 2010). According to Merrifield et al. (2010), there are only two viable ways of administration: via water or food. In addition, these authors suggest three possible probiotic regimens: short-term, only when needed; alternating short periods with and without the probiotic; and continuous probiotic exposure.

The snook (Centropomus spp.) is the most valued fish in the market of the state of São Paulo, Brazil (Companhia de Entrepostos e Armazéns Gerais do Estado de São Paulo, 2013); however, the depletion of its natural stocks has been reported in the estuary of Cananéia-Iguape, by Mendonça \& Katsuragawa (2001). Currently, in Southeast Brazil, there is a tendency to preserve the fish in their natural environment, with capture restrictions and protected seasons, and to develop new technologies that support their rearing in captivity.

The objective of this work was to evaluate the addition of Bacillus subtilis probiotic to the feed of common snook fingerlings, in alternate and continuous regimens.

\section{Materials and Methods}

The experiment was performed in the estuary of Cananéia-Iguape, in the municipality of Ilha
Comprida, in the state of São Paulo, Brazil (245'ㄹ' $20^{\prime \prime}$, $\left.47^{\circ} 48^{\prime} 01^{\prime \prime} \mathrm{W}\right)$. The region encompasses a large area of preserved mangroves and is influenced by marine and continental waters, mainly from the Ribeira de Iguape River, as well as other watercourses. Because it is an estuary region, there is great variation in water salinity, turbidity, and in tidal speed.

The trial was conducted in a completely randomized design, with three treatments and four replicates. Twelve cages with $1.3-\mathrm{m}^{3}$ volume each, measuring $1.0 \times 1.0 \times 1.3 \mathrm{~m}$, with $5.0 \times 5.0-\mathrm{mm}$ mesh were used. The cages were installed in three floating structures measuring $2.7 \times 3.0 \mathrm{~m}$, with four cages each. The cages were placed in a sheltered bay to avoid interferences in the experiment. The experimental period was of 191 days, from July to December 2012.

The common snook fingerlings were obtained from the Laboratory of Marine Acquaculture (Lapmar) of Universidade Federal de Santa Catarina, located in the municipality of Florianópolis, in the state of Santa Catarina, Brazil. Fish were transported in polyethylene bags filled with properly-oxygenated water. A total of 660 fish were acclimated to the experimental site for 45 days before trial conduction. Fifty-five fish with average length of $5.90 \pm 0.88 \mathrm{~cm}$ and average weight of $1.92 \pm 0.28 \mathrm{~g}$ were stocked in each cage and fed twice per day, until apparent satiety.

Diets were prepared with commercial feed (powder), previously moisturized with water in $2: 1 \mathrm{feed} /$ water ratio. Feed nutritional composition, in $\mathrm{g} \mathrm{kg}^{-1}$, was: 120 humidity (max.); 450 total protein (min.); 85 total fat (min.); 45 total fiber (max.); 140 minerals (max.); 15 calcium (min.); 38 calcium (max.); and 10 phosphorus (min.). This mixture was then pelleted and dried up to $12 \%$ humidity; pulverized into 1.0 , 2.0, or 4.0-mm particles (feed pellet size was increased according to fish growth, during the experiment); and, finally, sprayed with $2 \%$ soybean oil. The prepared feed was used as a control diet. The probiotic diet was prepared similarly to the diet described above, but was sprayed with soybean oil containing lyophilized B. subtilis (C-3102) at a concentration of $5.0 \times 10^{9} \mathrm{CFU}$ per $\mathrm{kg}$ of feed. These diets were prepared once a month and kept under refrigeration at $3-7^{\circ} \mathrm{C}$, as recommended by Aly et al. (2008).

The evaluated treatments were: control diet without probiotics, provided continuosly; probiotic diet, provided alternately with the control diet during 
7 days, in alternate regimen (T1); and probiotic diet exclusively, provided during the entire 191 days of the experiment, in continuous regimen (T2).

The alternate regimen adopted in $\mathrm{T} 1$ was determined based on data obtained in a previous study performed under laboratory conditions with fat snook (Centropomus parallelus) fingerlings. During the continuous probiotic diet, the phagocytic activity in fish increased during the initial 7 days but decreased afterwards. Therefore, the weekly alternation of diets was adopted due to this higher phagocytic activity in C. parallelus fingerlings. The phagocytic activity was determined according to Silva et al. (2002, 2005).

After being prepared and stored for 31 days, 100-g samples of the feed were sent to the Laboratory of Uniquímica-Ltda., in the municipality of São Paulo, in the state of São Paulo, Brazil, to check B. subtilis content. Samples were homogenized with sterile saline solution (1:1 ratio) and placed in a $65^{\circ} \mathrm{C}$ water bath for $35 \mathrm{~min}$. After a cool-down period, the samples were serially diluted four times $(500 \mu \mathrm{L}$ in $100 \mathrm{~mL})$, inoculated in typical soy agar (TSA) medium, and incubated at $37^{\circ} \mathrm{C}$ for 24 hours. Morphological checking of $B$. subtilis colonies was performed, and the positively identified ones were counted. Microbiological analyses showed B. subtilis probiotic concentration of $5 \times 10^{9} \mathrm{CFU} \mathrm{kg} \mathrm{kg}^{-1}$ in the feed, indicating bacterial viability for conservation at $3-7^{\circ} \mathrm{C}$; the presence of $B$. subtilis was not observed in the control feed, as expected.

The values of total length, total weight, and survival rate, $S=($ final fish count $\times 100) /$ initial fish count, were measured during the initial, intermediate ( 87 days), and final (191 days) biometries. The values of apparent feed conversion, $\mathrm{AFC}=$ feed consumption/weight gain, were obtained from feeding data, average weight gain, $\mathrm{WG}=$ final weight - initial weight, and survival (S) from each of the replicates. Fulton's condition factor (K) (Le Cren, 1951) and specific growth rate, $\mathrm{SGR}=((\ln$ final weight $-\ln$ initial weight $) /$ time $) \times 100$, were also calculated.

After 191 days, two fish from each replicate were euthanized via deep sedation in $100 \mathrm{mg} \mathrm{L}^{-1}$ benzocaine solution (Coyle et al., 2004), followed by medullar sectioning. The fish were then tagged, frozen, and sent to the Food Technology Institute, located in the state of São Paulo, Brazil, for analysis of body composition. Samples from each treatment were ground and homogenized for determination of: humidity at $105^{\circ} \mathrm{C}$ until weight was stable, ether extract (Soxhlet), total protein content (Kjeldahl $\mathrm{N} \times 6.25)$, and ash at $500^{\circ} \mathrm{C}$, according to Williams (1984).

At the end of the experimental period, another five fish from each treatment were euthanized with benzocaine solution (Coyle et al., 2004), and blood was collected from the caudal vein, with heparinized syringes and needles. The blood was immediately analyzed for: red blood cell count (RBC), performed with a Neubauer chamber; hematocrit (Ht), using the hematocrit method; and hemoglobin $(\mathrm{Hb})$, via the cyanmethemoglobin method. A blood smear was prepared and stained by the May-Grünwald-Giemsa method, according to Rosenfeld (1947), to perform the counts of differential and total leukocytes and of platelets, as in Hrubec \& Smith (2000).

To determine respiratory burst, after blood collection, cephalic kidneys were extracted, macerated with the plunger of a syringe against a $50-\mu \mathrm{m}$ mesh, and diluted in RPMI-1640 culture medium, with $20 \%$ bovine serum, $0.5 \%$ glutamine, and antibiotics. The cellular suspension obtained was transferred to $10-\mathrm{mL}$ Falcon tubes, with $50 \mu \mathrm{L}$ heparin, and the cell concentration was adjusted to $10^{7}$ phagocytes per $\mu \mathrm{L}$ of culture medium, using a Neubauer chamber. This medium was incubated for 2 hours in 96-well plates $(400 \mu \mathrm{L}$ each), sampled in duplicate. After the incubation period, the supernatant was discarded, each sample received $100 \mu \mathrm{L}$ RPMI medium, and the supernatant was discarded again. Then, each well received $100 \mu \mathrm{L}$ nitroblue tetrazolium (NBT), phorbol myristate acetate (PMA), and RPMI medium; subsequently, the plate was incubated for another hour to perform phagocytosis of NBT. The supernatant was once more discarded, and the wells were rinsed twice with $100 \mu \mathrm{L}$ phosphate-buffered saline (PBS). Then, $100 \mu \mathrm{L}$ methanol (70\%) were added to each well for macrophage lysis and consequent release of the formazan granules. To solubilize the precipitate, $120 \mu \mathrm{L} \mathrm{KOH} 2 \mathrm{~mol} \mathrm{~L}^{-1}$ and $140 \mu \mathrm{L}$ dimethyl sulfoxide (DMSO) were added to each well. The plate was then placed in a spectrophotometer, and the absorbance (A) at $630 \mathrm{~nm}$ was measured.

Data were subjected to analysis of variance (Anova), and means were compared by the Tukey test, at 5\% probability, using the SAS software (Cary, NC, USA). All data are presented as averages \pm standard deviation. 


\section{Results and Discussion}

Feed supplemented with $B$. subtilis probiotic bacteria did not significantly alter the zootechnical growth index in treated and untreated common snook (Table 1), possibly due to the fact that the used bacilli strain does not stimulate the digestion and absorption of nutrients in this fish species. Barbosa et al. (2011) also did not observe significant differences in the zootechnical index values after feeding fat snook with diet supplemented with Lactobacillus plantarum isolate of the Nile tilapia digestive tract.

Kennedy et al. (1998) reported a higher survival rate for common snook larvae in water containing

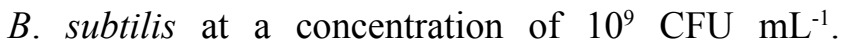
Moreover, Carnevali et al. (2006) found that European sea bass (Dicentrarchus labrax) presented an average increase of $81 \%$ in weight after 59 days of treatment with Lactobacillus delbrueckii probiotic. These authors supplemented the feed with probiotic bacteria directly isolated from the digestive tract of European sea bass. The adopted procedures suggest that probiotic strains isolated from the same species could improve the zootechnical index in saltwater fish, since the bacteria were acclimated to the digestive tract of the host and could perform their functions as a probiotic more efficiently.

No significant differences were observed in the corporal index among groups (Table 2), although the fish from the alternate regimen have apparently shown lower accumulation of muscle and body fat. Barbosa et al. (2011) also did not find any improvement in the body composition of fat snook fed with L. plantarum.

Table 1. Growth parameters of common snook (Centropomus undecimalis) fed diets with and without (control) Bacillus subtilis probiotic, in alternate and continuous regimen, during 191 days $^{(1)}$.

\begin{tabular}{lccc}
\hline Parameter & Control & Alternate & Continuous \\
\hline Total length $(\mathrm{cm})$ & $9.7 \pm 0.9$ & $9.4 \pm 0.9$ & $10.1 \pm 0.7$ \\
Total weight $(\mathrm{g})$ & $7.9 \pm 1.1$ & $6.5 \pm 1.4$ & $8.7 \pm 1.5$ \\
Weight gain $(\mathrm{g})$ & $6.0 \pm 1.1$ & $4.6 \pm 1.4$ & $6.8 \pm 1.5$ \\
Apparent feed conversion & $15.4 \pm 3.8$ & $19.6 \pm 5.26$ & $12.6 \pm 1.77$ \\
Specific growth rate (\%) & $0.73 \pm 0.7$ & $0.63 \pm 0.1$ & $0.78 \pm 0.1$ \\
Fulton factor ${ }^{(2)}$ & $0.87 \pm 0.1$ & $0.78 \pm 0.1$ & $0.83 \pm 0.1$ \\
Survival $(\%)$ & $68.6 \pm 11.3$ & $71.36 \pm 12.8$ & $70.90 \pm 18.8$ \\
\hline
\end{tabular}

(1)No significant differences were observed among treatments by analysis of variance, at $5 \%$ of probability. ${ }^{(2)}$ Fulton factor (Le Cren, 1951).
The values of respiratory burst, expressed as optical density $(630 \mathrm{~nm})$, were $0.470,0.997$, and 0.417 , respectively, for control, alternate regimen, and continuous regimen, showing a higher oxygen consumption in the alternate regimen during the phagocytosis process. The alternate probiotic regimen improved the immune system of the fish, consequently yielding a higher protection against natural pathogens (Bricknell \& Dalmo, 2005). Geng et al. (2011) also reported an increase in the respiratory burst in cobia (Rachycentron canadum) that daily received a diet supplemented with a mix of chitosan and B. subtilis. However, Díaz-Rosales et al. (2006) and Cerezuela et al. (2012) did not observe significant differences in the respiratory burst of sea bream (Sparus aurata) fed with probiotics.

The continuous feeding of probiotics did not increase the immune system activity of common snook, since the values of respiratory burst in fish from this group were similar to those of the control. This data is in agreement with those of Bricknell \& Dalmo (2005), who observed that continuous exposure to elevated concentrations or continued exposure to probiotics may fail in stimulating the fish's immune system due to the resistance induced by the host. Merrifield et al. (2010) reported that the continuous use of immunostimulant substances could decrease the activity of the immune system and, in some cases, even trigger immunosuppression.

Among the analyzed blood parameters, treatments did not alter the total amount of hemoglobin or leukocyte and thrombocyte counts (Table 3). Barbosa et al. (2011) found higher rates of leukocytes, thrombocytes, and lymphocytes in fish treated with probiotics, when compared to the control, contrary to

Table 2. Whole body chemical composition of common snook (Centropomus undecimalis) fed diets with and without (control) Bacillus subtilis probiotic, in alternate and continuous regimen, during 191 days $^{(1)}$.

\begin{tabular}{|c|c|c|c|c|}
\hline \multirow{2}{*}{ Treatment } & Moisture & Proteins & Ash & Ether extract \\
\hline & \multicolumn{4}{|c|}{ 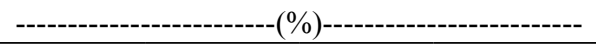 } \\
\hline Control & 75.24 & 18.48 & 4.48 & 1.07 \\
\hline Alternate & 75.46 & 17.43 & 5.41 & 0.73 \\
\hline Continuous & 76.15 & 18.14 & 4.72 & 0.92 \\
\hline
\end{tabular}


Table 3. Hematological parameters of common snook (Centropomus undecimalis) fed diets with and without (control) Bacillus subtilis probiotic, in alternate and continuous regimen, during 191 days $^{(1)}$.

\begin{tabular}{lccc}
\hline Parameters & Control & Alternate & Continuous \\
\hline Red blood cells $\left(10^{6} \mu \mathrm{L}^{-1}\right)$ & $4.19 \pm 0.33 \mathrm{a}$ & $3.5 \pm 0.52 \mathrm{~b}$ & $4.76 \pm 0.6 \mathrm{a}$ \\
Hemoglobin $(\mathrm{g} \mathrm{dL}-1)$ & $5.99 \pm 0.99$ & $5.18 \pm 0.33$ & $5.16 \pm 0.48$ \\
Leukocytes $\left(10^{3} \mu \mathrm{L}^{-1}\right)$ & $24.96 \pm 27.1$ & $24.07 \pm 23.63$ & $23.13 \pm 7.37$ \\
Lymphocytes $\left(10^{3} \mu \mathrm{L}^{-1}\right)$ & $6.57 \pm 7.62$ & $9.31 \pm 14.50$ & $9.74 \pm 2.89$ \\
Neutrophils $\left(10^{3} \mu \mathrm{L}^{-1}\right)$ & $12.49 \pm 1.23$ & $9.33 \pm 7.73$ & $10.63 \pm 7.11$ \\
Monocytes $\left(10^{3} \mu \mathrm{L}^{-1}\right)$ & $5.89 \pm 7.97$ & $5.23 \pm 6.77$ & $2.66 \pm 1.48$ \\
Thrombocytes $\left(10^{3} \mu \mathrm{L}^{-1}\right)$ & $41.99 \pm 24.1$ & $32.28 \pm 12.04$ & $1.37 \pm 18.07$ \\
\hline
\end{tabular}

${ }^{(1)}$ Means followed by equal letters do not differ significantly by the Tukey test, at $5 \%$ probability. $\mathrm{n}=5$.

the data obtained in the present study. However, fish from the alternate regimen presented a significantly lower amount of erythrocytes (RBC) when compared to those of the control and the continuous regimen. Contrasting with these results, animals exposed to probiotics generally present higher $\mathrm{RBC}$ and leucocyte counts, due to the immunological capacity of probiotics (Talpur et al., 2014). In the present study, the resistance induced by the continuous probiotic supply may not have interfered with the production of $\mathrm{RBC}$ in fish from the continuous regime, as opposed to the observed in the fish from the alternate regime, which presented anemia.

\section{Conclusions}

1. Adding Bacillus subtilis to the feed of common snook (Centropomus undecimalis) fingerlings stimulates the immune system in the alternate regimen.

2. The addition of B. subtilis does not improve the growth rate of the fish, independently of feed regimen.

\section{Acknowledgments}

To Conselho Nacional de Desenvolvimento Científico e Tecnológico (CNPq), for financial support; to Coordenação de Aperfeiçoamento de Pessoal de Nível Superior (Capes), for scholarship granted; to Guilherme Silveira Telli, for help with the statistical analyses; to André Koga, for help with the analysis of the respiratory burst data; and to the biologist Diógenes Dorta Filho, for maintaining the fish.

\section{References}

ALY, S.M.; AHMED, Y.A.-G.; GHAREEB, A.A.-A.; MOHAMED, M.F. Studies on Bacillus subtilis and Lactobacillus acidophilus, as potential probiotics, on the immune response and resistance of Tilapia nilotica (Oreochromis niloticus) to challenge infections. Fish and Shellfish Immunology, v.25, p.128-136, 2008. DOI: 10.1016/j.fsi.2008.03.013.

BALCÁZAR, J.L.; BLAS, I. de; RUIZ-ZARZUELA, I.; VENDRELL, D.; GIRONÉS, O.; MUZQUIZ, J.L. Enhancement of the immune response and protection induced by probiotic lactic acid bacteria against furunculosis in rainbow trout (Oncorhynchus mykiss). FEMS Immunology and Medical Microbiology, v.51, p.185-193, 2007. DOI: 10.1111/j.1574695X.2007.00294.X.

BARBOSA, M.C.; JATOBÁ, A.; VIEIRA, F. do N.; SILVA, B.C.; MOURINO, J.L.P.; ANDREATTA, E.R.; SEIFFERT, W.Q.; CERQUEIRA, V.R. Cultivation of juvenile fat snook (Centropomus parallelus Poey, 1860) fed probiotic in laboratory conditions. Brazilian Archives of Biology and Technology, v.54, p.795-801, 2011. DOI: 10.1590/ S1516-89132011000400020.

BRICKNELL, I.; DALMO, R.A. The use of immunostimulants in fish larval aquaculture. Fish and Shellfish Immunology, v.19, p.457-472, 2005. DOI: 10.1016/j.fsi.2005.03.008.

CARNEVALI, O.; DE VIVO, L.; SULPIZIO, R.; OLIVOTTO, I.; SILVI, S.; CRESCI, A. Growth improvement by probiotic in European sea bass juveniles (Dicentrarchus labrax, L.), with particular attention to IGF-1, myostatin and cortisol gene expression. Aquaculture, v.258, p.430-438, 2006. DOI: 10.1016/j.aquaculture.2006.04.025.

CEREZUELA, R.; GUARDIOLA, F.A.; GONZÁlEZ, P.; MESEGUER, J.; ESTEBAN, M.A. Effects of dietary Bacillus subtilis, Tetraselmis chuii, and Phaeodactylum tricornutum, singularly or in combination, on the immune response and disease resistance of sea bream (Sparus aurata L.). Fish and Shellfish Immunology, v.33, p.342-349, 2012. DOI: 10.1016/j. fsi.2012.05.004.

COMPANHIA DE ENTREPOSTOS E ARMAZÉNS GERAIS DO ESTADO DE SÃO PAULO. Preços no atacado. Categoria: Pescado. Data: 15/05/2013. Disponível em: <http://www. ceagesp.gov.br/cotacoes/>. Acesso em: 15 maio 2013.

COYLE, S.D.; DURBOROW, R.M.; TIDWELL, J.H. Anesthetic in aquaculture. College Station: Southern Regional Aquaculture Center, 2004. 6p. (SRAC Publication, 3900).

DIAS, D.C.; LEONARDO, A.F.G.; TACHIBANA, L.; CORREAA, C.F.; BORDON, I.C.A.C.; ROMAGOSA, E.; RANZANI-PAIVA, M.J.T. Effect of incorporating probiotics into the diet of matrinxã (Brycon amazonicus) breeders. Journal of Applied Ichthyology, v.28, p.40-45, 2012. DOI: 10.1111/j.1 439-0426.2011.01892.x.

DÍAZ-ROSALES, P.; SALINAS, I.; RODRÍGUEZ, A.; CUESTA, A.; CHABRILLÓN, M.; BALEBONA, M.C.; MORIÑIGO, M.A.; ESTEBAN, M.A.; MESEGUER, J. Gilthead seabream (Sparus aurata L.) innate immune response after 
dietary administration of heat-inactivated potential probiotics. Fish and Shellfish Immunology, v.20, p.482-492, 2006. DOI: 10.1016/j.fsi.2005.06.007.

GATESOUPE, F.J. The use of probiotics in aquaculture. Aquaculture, v.180, p.147-165, 1999. DOI: 10.1016/ S0044-8486(99)00187-8.

GENG, X.; DONG, X.-H.; TAN, B.-P.; YANG, Q.-H.; CHI, S.-Y.; LIU, H.-Y.; LIU, X.-Q. Effects of dietary chitosan and Bacillus subtilis on the growth performance, non-specific immunity and disease resistance of cobia, Rachycentron canadum. Fish and Shellfish Immunology, v.31, p.400-406, 2011. DOI: 10.1016/j. fsi.2011.06.006.

HRUBEC, T.C.; SMITH, S.A. Hematology of fish. In: FELDMAN, B.F.; ZINKL, J.G.; JAIN, N.C. (Ed.). Schalm's Veterinary Hematology. $5^{\text {th }}$ ed. Philadelphia: Lippincott Williams \& Wilkins, 2000. p.1120-1125.

JATOBÁ, A.; VIEIRA, F. do N.; BUGLIONE NETO, C.; SILVA, B.C.; MOURIÑO, J.L.P.; JERÔNIMO, G.T.; DOTTA, G.; MARTINS, M.L. Utilização de bactérias ácido-láticas isoladas do trato intestinal de tilápia-do-nilo como probiótico. Pesquisa Agropecuária Brasileira, v.43, p.1201-1207, 2008. DOI: 10.1590/ S0100-204X2008000900015.

KENNEDY, S.B.; TUCKER Jr., J.W.; NEIDIG, C.L.; VERMEER, G.K.; COOPER, V.R.; JARRELL, J.L.; SENNETT, D.G. Bacterial management strategies for stock enhancement of warmwater marine fish: a case study with common snook (Centropomus undecimalis). Bulletin of Marine Science, v.62, p.573-588, 1998.

LE CREN, E.D. The length-weight relationship and seasonal cycle in gonad weight and condition in the perch (Perca fluviatilis). Journal of Animal Ecology, v.20, p.201-219, 1951. DOI: $10.2307 / 1540$.

MENDONÇA, J.T.; KATSURAGAWA, M. Caracterização da pesca artesanal no complexo estuarino-lagunar de Cananéia-Iguape, Estado de São Paulo, Brasil (1995-1996). Acta Scientiarum. Biological Sciences, v.23, p.535-547. 2001. DOI: 10.4025/ actascibiolsci.v23i0.2713.

MERRIFIELD, D.L.; DIMITROGLOU, A.; FOEY, A.; DAVIES, S.J.; BAKER, R.T.M.; BOGWALD, J.; CASTEX, M.; RINGO, E. The current status and future focus of probiotic and prebiotic applications for salmonids. Aquaculture, v.302, p.1-18, 2010. DOI: 10.1016/j.aquaculture.2010.02.007.
NAYAK, S.K. Probiotics and immunity: a fish perspective. Fish and Shellfish Immunology, v.29, p.2-14, 2010. DOI: 10.1016/j. fsi.2010.02.017.

ROSENFELD, G. Método rápido de coloração de esfregaços de sangue: noções práticas sobre corantes pancrômicos e estudo de diversos fatores. Memórias do Instituto Butantan, v.20, p.315-328, 1947.

SCHREZENMEIR, J.; VRESE, M. de. Probiotics, prebiotics, and synbiotics: approaching a definition. American Journal of Clinical Nutrition, v.73, p.361-364, 2001.

SILVA, J.R.M.C.; PORTO-NETO, L.R.; BORGES, J.C.S.; JENSCH-JUNIOR, B.E. Germicide capacity of macrophages (MØ) in the Antarctic fish Notothenia coriiceps (Richardson, 1844) at $0^{\circ} \mathrm{C}$. Polar Biology, v.28, p.326-328, 2005.

SILVA, J.R.M.C.; STAINES, N.A.; HERNANDEZ-BLAZQUEZ, F.J.; PORTO-NETO, L.R.; BORGES, J.C.S. Phagocytosis and giant cell formation at $0^{\circ} \mathrm{C}$ by macrophage (MØ) of Notothenia coriiceps. Journal of Fish Biology, v.60, p.466-478, 2002. DOI: 10.1111/j.1095-8649.2002.tb00294.x.

SON, V.M.; CHANG, C.-C.; WU, M.-C.; GUU, Y.-K.; CHIU, C.-H.; CHENG, W. Dietary administration of the probiotic, Lactobacillus plantarum, enhanced the growth, innate immune responses, and disease resistance of the grouper Epinephelus coioides. Fish and Shellfish Immunology, v.26, p.691-698, 2009.

TALPUR, A.D.; MUNIR, M.B.; MARY, A.; HASHIM, R. Dietary probiotics and prebiotics improved food acceptability, growth performance, haematology and immunological parameters and disease resistance against Aeromonas hydrophila in snakehead (Channa striata) fingerlings. Aquaculture, v.426-427, p.14-20, 2014. DOI: 10.1016/j.aquaculture.2014.01.013.

VERSCHUERE, L.; ROMBAUT, G.; SORGELOOS, P.; VERSTRAETE, W. Probiotic bacteria as biological control agents in aquaculture. Microbiology and Molecular Biology Reviews, v.64, p.655-671, 2000. DOI: 10.1128/ MMBR.64.4.655-671.2000.

WANG, Y.-B. Effect of probiotics on growth performance and digestive enzyme activity of the shrimp Penaeus vannamei. Aquaculture, v.269, p.259-264, 2007. DOI: 10.1016/j.aquaculture.2007.05.035.

WILLIAMS, S. (Ed.). Official methods of analysis of the Association of Official Analytical Chemists. $14^{\text {th }}$ ed. Arlington: AOAC International, 1984.

Received on December 18, 2014 and accepted on March 26, 2015

Pesq. agropec. bras., Brasília, v.50, n.4, p.267-272, abr. 2015

DOI: 10.1590/S0100-204X2015000400001 